Historia Slavorum Occidentis

2018, nr 1 (16)

ISSN 2084-1213

DOI: $10.15804 /$ hso180101

\author{
Marcin GomóŁKa (Siedlce)
}

\title{
Wpływ szyku taborowego husytów na polską sztukę wojenną XV-XVII w. Zarys problematyki
}

Słowa kluczowe: szyk taborowy, Polska, sztuka wojenna

Keywords: wagon fort, Poland, art war

\begin{abstract}
The introduction of the paper discusses the purposes, thesis statement and the present state of research. The main body analyses the influence of the Hussite wagon fort on the Polish warfare of the $15^{\text {th }}-17^{\text {th }}$ century. The summary contains conclusions concerning the use of the wagon fort on the battlefield by the Polish army.
\end{abstract}

\section{Wstęp}

Niniejszy artykuł dotyczy wpływu stosowanego przez czeskich husytów szyku taborowego na rozwój polskiej wojskowości w XV-XVII w. Zasygnalizowany przedział czasowy, choć stosunkowo szeroki, właściwie obrazuje recepcję taboru przez armię polską i jego praktyczne użycie na polu bitwy. Głównym celem determinującym podjęcie wspomnianej problematyki badawczej jest chęć prezentacji możliwości zastosowania taboru w walce. Podstawą realizacji przyjętego zamierzenia będzie analiza wybranych bitew stoczonych przez wojska polskie i Rzeczpospolitej Obojga Narodów, w sposób modelowy ilustrujących użycie taboru w różnych wariantach. Inne z założeń wiążą się z pokazaniem ewolucji taboru, jak również recepcji pomysłów husyckich na grunt polski. Przyjęta hipoteza badawcza skłania do wysunięcia stwierdzenia, że oddziaływanie czy też wpływ szyku taborowego na polską sztukę 
wojenną w XV-XVII w. był znaczący. Korzystając ze wzorców i rozwiązań stworzonych przez czeskich husytów, niekiedy modyfikując je w zależności od teatru działań wojennych, polscy wodzowie potrafili skutecznie użyć taboru w różnych, często bardzo niesprzyjających okolicznościach taktyczno-operacyjnych, doprowadzając do jego znaczącej ewolucji na przestrzeni dziejów.

Poza meritum czyli zarysowaniem roli taboru husyckiego w rozwoju polskiej wojskowości w XV-XVII w., w artykule przedstawiono również jego genezę, przeznaczenie, a także organizację. Zabieg taki jest konieczny w kontekście podejmowanej problematyki badawczej.

Temat recepcji taboru husytów na potrzeby polskiej sztuki wojennej omawiano już w literaturze przedmiotu. Z badaczy zajmujących się tą problematyką należy wymienić przede wszystkim: Mariana Biskupa ${ }^{1}$, Macieja Franza ${ }^{2}$, Michała Gawędę ${ }^{3}$, Tadeusza Korzona ${ }^{4}$, Mariana Kukiela ${ }^{5}$, Tadeusza Nowaka i Jana Wimmera ${ }^{6}$, Marka Plewczyńskiego ${ }^{7}$, Władysława Serczyka ${ }^{8}$, Janusza Sikorskiego ${ }^{9}$. Ich prace posiadały charakter zarówno ogólny, dotyczący specyfiki taboru husyckiego i jego wplywu na rozwój polskiej wojskowości w wiekach późniejszych (T. Korzon, M. Kukiel, T. Nowak oraz J. Wimmer, J. Sikorski), jak i bardziej szczegółowy, traktujący o przebiegu danej bitwy (M. Biskup, M. Plewczyński). Niezwykle cenne, głównie w kontekście analizy starcia pod Kumejkami okazały opracowania dotyczące problematyki kozackiej (M. Franz., M. Gawęda, W. Serczyk).

\section{Geneza taboru}

Rozważania dotyczące szyku taborowego należy rozpocząć od zdefiniowania tego sposobu ustawienia wojsk. Szyk taborowy (tabor) była to ruchoma forteca złożona

\footnotetext{
1 M. Biskup, Wojna trzynastoletnia, Kraków 1990.

2 M. Franz, Wojskowość Kozaczyzny Zaporoskiej w XVI-XVII wieku, Toruń 2002.

3 M. Gawęda, Powstanie kozackie 1637, Zabrze 2007.

4 T. Korzon, Dzieje wojen i wojskowości w Polsce. Epoka przedrozbiorowa, t. 1, Lwów-Warszawa-Kraków 1923.

5 M. Kukiel, Zarys historii wojskowości w Polsce, Kraków 1929.

6 T.M. Nowak, J. Wimmer, Historia oręża polskiego 963-1795, Warszawa 1981.

7 M. Plewczyński, Wojny i wojskowość polska XVI wieku, t. 1, Zabrze 2011.

8 W. Serczyk, Na dalekiej Ukrainie. Dzieje Kozaczyzny do 1648 roku, Kraków 2008.

9 J. Sikorski, Zarys historii wojskowości powszechnej do końca XIX wieku, Warszawa 1972.
} 
z wozów (z niem. Wagenburg), używana początkowo w celach typowo defensywnych, jako zapora przeciwko konnicy, następnie zaś wykorzystywana do burzenia szyku i spychania wojsk nieprzyjacielskich z pola bitwy ${ }^{10}$.

W wariancie typowo defensywnym tabor stosowano już w późnej starożytności. W bitwie pod Adrianopolem w 378 r. obóz gocki obwarowany był wozami, które połączono łańcuchami. Rzymski historyk Ammian Marcellinus zapisał, że tabor posiadał kształt bardzo regularnego koła ${ }^{11}$. Odegrał on w bitwie rolę obronną, osłaniając gockich piechurów przed atakiem rzymskiej pieszej gwardii pałacowej (scutarii i sagittarii) oraz jazdy. W momencie klęski gwardzistów tabor zaatakowało nie do końca jeszcze uformowane lewe skrzydło Rzymian ${ }^{12}$. Zamknięci wewnątrz taboru wojownicy goccy wiązali Rzymian aż do momentu przybycia własnej konnicy, która wpadła w lukę pomiędzy zbyt wysuniętą kawalerią rzymską a oddziałami dochodzącymi do taboru ${ }^{13}$. Był to przełomowy moment starcia. Goci rozbili rzymską jazdę, co spowodowało odsłonięcie obu flanek armii rzymskiej i w konsekwencji zniszczenie piechoty ${ }^{14}$. Pod Adrianopolem polegal cesarz Walens ${ }^{15}$ oraz 2/3 jego wojsk ${ }^{16}$.

$\mathrm{Z}$ analizy przebiegu bitwy wynika kilka zasadniczych wniosków. Mianowicie pokazała ona, że obóz obwarowany taborem może odgrywać ważną rolę na polu bitwy, jako zabezpieczenie przed atakiem jazdy, jak również oparcie dla silnego kontrataku piechoty wychodzącego spoza wozów na wykrwawionego przeciwnika. Właściwe zastosowanie taboru minimalizowało różnice w wyszkoleniu wojskowym armii atakującej i znajdującej się wewnątrz fortecy. Znakomicie wyćwiczeni rzymscy gwardziści oraz jazda nie potrafili przełamać ustawionej w taborze i dobrze broniącej się gockiej piechoty. Analiza starcia pozwala stwierdzić, iż umiejętnie prowadzona $\mathrm{w}$ oparciu o tabor obrona umożliwiała w wypadku osłabienia przeciwnika wyprowa-

10 Ch. Allmand, Nowa broń i nowa taktyka 1300-1500, [w: ] Historia sztuki wojennej, red. G. Parker, Warszawa 2008, s. 109.

11 A. Marcellinus, Dzieje rzymskie, t. 2, przeł. I. Lewandowski, Warszawa 2002, XXXI, 12, 11, s. 254 .

12 Tamże, XXXI, 13, 2, s. 256.

13 P. Orosius, The seven books of history against the pagans, transl. R. J. Deferrari, Washington 1964, tu VII, 33, 12, s. 304-305.

14 K. Narloch, Podstawowe zadania oraz taktyka późnorzymskiej jazdy. Studium wybranych bitew, [w: ] Do szarży marsz, marsz. Studia z dziejów kawalerii, red. A. Smoliński, Toruń 2015, s. 47.

15 A. Marcellinus, Dzieje rzymskie, XXXI, 13, 12, s. 258.

16 Tamże, XXXI, 13, 18, s. 259. 
dzanie szybkich uderzeń flankowych, często decydujących o wyniku batalii. Podsumowując warto zaznaczyć, że pod Adrianopolem gocki tabor pełnił rolę spoiwa dla optymalnego współdziałania piechoty i jazdy. To właśnie barbarzyńscy piechurzy, oczekując na przybycie własnej konnicy, powstrzymali impet ataku rzymskiej gwardii i jazdy, kawaleria zaś uderzyła na oddalonych od własnych stanowisk Rzymian. Szarżę wspomagali wychodzący z taboru piechurzy. Doskonale zsynchronizowana w oparciu o tabor synergia gockiej piechoty i jazdy była tym czynnikiem, który w głównej mierze zadecydował o zwycięstwie.

\section{Przeznaczenie taboru husyckiego}

Zastosowanie taboru, przede wszystkim w wariancie defensywnym, i w mniejszym stopniu ofensywnym (kontratak z wnętrza fortecy) do perfekcji doprowadzili w XV w. czescy husyci ${ }^{17}$.

Rebelia husytów w Pradze w 1419 r., a rok później na terenie całych Czech ${ }^{18}$ przyczyniła się do zastosowania szyku wozowego na skalę masową na polu bitwy, wpłynęła również na jego postępującą ewolucję. Tabor przestał bowiem pełnić rolę

17 Czeski ruch o podłożu religijno-narodowościowym, akcentujący konieczność reform w kościele rzymskokatolickim oraz skierowany przeciwko dynastii Luksemburgów. Postulaty religijne husytów nawoływały do swobodnego głoszenia Słowa Bożego, komunii pod dwiema postaciami, sekularyzacji dóbr kościelnych. Poglądy te kościół katolicki uznawał za heretyckie. Ideologiem ruchu husyckiego był spalony na stosie w lipcu 1415 r. profesor uniwersytetu w Pradze Jan Hus. Na temat husytyzmu w polskiej literaturze przedmiotu informowali: P. Boryszewski, Katolicyzm, jago instytucjonalizacja i sekularyzacja w Europie Środkowo-Wschodniej, Warszawa 2006; S. Bylina, Ruchy heretyckie w średniowieczu. Studia, Wrocław 1991; M. Lambert, Średniowieczne herezje, Gdańsk-Warszawa 2002; K. Moskal, Aby lud byt jeden - eklezjologia Jana Husa w traktacie De ecclesia, Lublin 2003; A. Paner, Jan Hus, Kraków 2002; taż, Luksemburgowie w Czechach, Gdańsk, 2004; A. Prochaska, Czasy husyckie, Kraków 1998; G. Ryś, Jan Hus wobec kryzysu Kościoła doby wielkiej schizmy, Kraków 2000; L. Żuk, Chrześcijańskie herezje, sekty i kościoły, Wrocław 2002.

18 Literatura polskojęzyczna i obcojęzyczna dotycząca wojen husyckich i podziałów w ruchu husyckim zob. m.in. S. Bylina, Na skraju lewicy husyckiej, Warszawa 2005; tenże, Hussitica. Studia, Warszawa 2007; tenże, Rewolucja husycka. Przedświt i pierwsze lata, t.1, Warszawa 2011; tenże, Rewolucja husycka. Czas chwaty i zmierzchu, t.2, Warszawa 2015; H. Kaminsky, A History of the Hussite Revolution, Berkeley-Los Angeles 1967; P. Marczak, Wojny husyckie, Warszawa 2004; A. Paner, Jan Žižka z Trocnova, Gdańsk 2002; M. Polivka, Bitva na Vitkove, Praha 1987; F. Seibt, Hussitica zur Struktur eine Revolution, Köln-Graz 1965; F. Smahel, Husitska revoluce, t. 1-4, Praha 1993; V.V. Tomek, Déjiny valék husitských (1419-1436), Praha 1898; J. Wysmulek, Stos od którego zgorzat caly kraj. Historia rewolucji husyckiej, Kraków 2010. 
osłony obozu, stając się fortecą dla całości armii. Żyjący w XV w. francuski pisarz i dyplomata Gilles le Bouvier podkreślał, iż cesarz i książęta niemieccy usiłowali siłą zdławić powstanie husyckie. W szeregu starć zbrojnych ponieśli jednak klęski spowodowane zastosowaniem przez husytów taboru. G. le Bouvier podał w swej relacji jeszcze dwa ważne szczegóły. Stwierdził mianowicie, iż siłę taboru wzmacniała znajdująca się w jego wnętrzu artyleria (wielkie ciężkie kije, ołowiane kule), walczący zaś wewnątrz fortecy żołnierze opuszczali ją wyjątkowo rzadko ${ }^{19}$.

Analizując treść źródła dochodzimy do wniosku, że tabor przynajmniej w początkach powstania husyckiego odgrywał rolę wybitnie defensywną, mając za zadanie niwelować przewagę wojsk cesarskich w otwartym polu i chronić żołnierzy armii husyckiej. Artyleria była natomiast czynnikiem wzmacniającym tabor, służącym zarówno do rażenia, jak i osłabiania atakujących. Z zawartych w źródle informacji nie wynika, czy na wykrwawionego przeciwnika wychodził kontratak z taboru. Wydaje się to jednak bardzo prawdopodobne, zważywszy na specyfikę prowadzenia walki w oparciu o wozy. W bitwie taborytów oraz utrakwistów pod Horicami 27 IV 1423 r. radykałowie długo bronili się zza taboru, następnie wyprowadzili skuteczny kontratak jazdy, zupełnie niszcząc przeciwnika. Podobny przebieg miało starcie pod Starym Wielisławiem 27 XII 1428 r., gdzie klęskę poniósł książę ziębicki Jan ${ }^{20}$. Można zatem założyć, że husyci używali taboru w dwóch wariantach. Mianowicie defensywnym, zorientowanym na obronę zgromadzonej w fortecy armii i zadanie jak największych strat atakującemu przeciwnikowi za pomocą skutecznego ognia artylerii oraz ofensywnym, którego istotą był atak z wnętrza taboru na flanki nieprzyjaciela i jego zupełne rozbicie.

19 G. le Bouvier, Le livre de la description de Pays, Paris 1908, s. 116.

20 Literatura poświęcona wojskowości husyckiej zob. m.in. W. Dziewanowski, Podręcznik do historii wojskowości powszechnej. Średniowiecze, Oświęcim 2012; R. Primke, M. Szczerepa, W. Szczerepa, Wojny husyckie na Ślasku, Łużycach i Pomorzu, Kraków 2007; E. Wagner, Jak válčili husité, Praha 1946; M. Wulf, Die hussitische Wagenburg, Berlin 1899; K. Ziółkowski, Cieżkozbrojna jazda kopijnicza w wojskach husyckich w latach 1419-1434, [w:] Pancerzu przez wieki. Z dziejów wojskowości polskiej i powszechnej, red. M. Baranowski, A. Gładysz, A. Niewiński, t. 2, Oświęcim 2014; tenże, Europa Środkowa bez granic. Działalność husyckich wojsk polnych w latach 1428-1433, [w:] Kresy, granice i pogranicza w historii wojskowej, red. A. Olejko, J. Ślipiec, P. Korzeniowski, K. Mroczkowski, Oświęcim 2014; tenże, Husyckie wojska polne. Ksztatt i organizacja armii (praca doktorska, UAM Poznań), Poznań 2015. 


\section{Ustawienie, organizacja i uzbrojenie}

W momencie rozpoczęcia bitwy tabor w zależności od ukształtowania terenu ${ }^{21}$, ustawiano $\mathrm{w}$ krąg lub czworobok ${ }^{22}$. Poszczególne wozy starano się zgrupować w jeden albo kilka rzędów, łącząc je łańcuchami (tzw. połączenie „koło w koło”)23. Zajmowały one w stosunku do siebie położenie skośne, stykając się rogami.

Pod względem taktycznym tabor dzielił się na straż przednią, hufiec walny oraz straż tylną. Marsz regulowano za pośrednictwem chorągwi sygnałowych. Wozy tworzące czoło kolumny wchodziły w skład tzw. skrzydła, które zamykało przednią bramę szyku. Z kolei wozy końcowe tworzyły zamknięcie, rygiel dla tylnej bramy szyku. W przerwach pomiędzy poszczególnymi wozami rozmieszczano artylerię. Zadania wewnątrz taboru były ściśle podzielone. Część żołnierzy zajmowała się tylko obroną wozów, pozostali (głównie jazda i częściowo piechota) wchodzili do bitwy w późniejszym etapie ${ }^{24}$.

Każdy z wozów stanowił w zasadzie odrębną jednostkę bojową. Jego załogę tworzyło 18 żołnierzy (czterech cepników, sześciu kuszników, dwóch strzelców uzbrojonych w broń palną, czterech włóczników i dwóch woźniców) ${ }^{25}$. W skład wyposażenia wozów wchodziły topory, grace, rydle, bosaki, proch, kule, żłób dla koni. Wymienione urządzenia służyły do prac saperskich, żłób zaś podczas bitwy wypełniano kamieniami, którymi rażono napastników. Pięć wozów tworzyło zastęp, zaś dziesięć jednostkę organizacyjną dowodzoną przez dziesiętnika. Zadaniem dziesiętnika było nadzorowanie szyku wozów w marszu. Zastępy łączyły się w rzędy. Rzędami kierował hetman rzędu, całym taborem zaś hetman wozów podlegający naczelnemu hetmanowi. W trakcie marszu wozy skrajne osłaniały resztę taboru przed

21 Tabor bardzo często formowano na wzniesieniach, starano się także wykorzystywać naturalne przeszkody terenowe, które chroniłyby dostęp do wozów (puste stawy, rowy, bagna). W starciu pod Sudomierzem Jan Žižka oparł jedno ze swych skrzydeł o wąską groblę, co w znacznym stopniu przyczyniło się do wzmocnienia współpracy pomiędzy wozami i odparcia liczniejszego przeciwnika; P. Cornej, P. Bylina, Slavné bitvy naší historie, Praga 1993, s. 40.

22 W XVII w. pojawił się także tabor trójkątny, stosowany przez Kozaków zaporoskich.

23 Chodziło w tym przypadku o połączenie prawego tylnego koła wozu poprzedniego z lewym przednim kołem kolejnego wozu.

24 P. Marczak, Wojny husyckie, s. 45.

25 Takie dane odnośnie liczebności husyckiego wozu podaje Śląski Regulamin Wozowy z 1429 r., zob. K. Ziółkowski, Husyckie wojska polne, s. 172. 
niespodziewanym atakiem wroga. $Z$ tych też względów było ich dwa razy więcej niż wozów wewnętrznych. Tabor ubezpieczany był także przez lekką jazdę oraz pawężników, którzy starali się nie dopuścić do ataku z boków. Dziennie tabor pokonywał odległość około $12 \mathrm{~km}$, posuwając się kolumnami bądź jednym rzędem wozów ${ }^{26}$.

Na wyposażeniu piechoty husyckiej znajdowała się broń biała oraz palna. Przykładem broni białej były miecze, zaopatrzone w haki glewie ${ }^{27}$, włócznie ${ }^{28} \mathrm{i}$ cepy bojowe. Bardzo przydatny oręż stanowiła wekiera, wykorzystywana głównie do rozbijania hełmu bądź zbroi przeciwnika ${ }^{29}$. Podobne przeznaczenie posiadał topór. Szybkie pchnięcia w bezpośrednim starciu zadawano natomiast kordem, ewentualnie puginałem. Broń białą piechoty husyckiej uzupełniały czekany, halabardy oraz młoty ${ }^{30}$. Stosowana przez piechotę ręczna broń palna to przede wszystkim piszczele i hakownice. Broń ta odznaczała się różną budową, rozmiarami jak również szerokością lufy. Ze względu, że dopiero się rozwijała, to była jeszcze stosunkowo prymitywna. Piszczele cechowały się wąską lufą, którą osadzano na drewnianym uchwycie. Hakownice mocowano zaś na drewnianej lawecie o długości około 1,5 m. Długość lufy natomiast kształtowała się w przedziale $30-90 \mathrm{~cm}^{31}$. Zarówno piszczele, jak i hakownice ładowano od przodu, odpalając nasmołowanym lontem, ewentualnie rozgrzanym żelazem. Uzbrojenie ochronne piechurów stanowiły pawęże, kaptury materiałowe bądź kolcze, napierśniki, nakolanniki, osłony ud i bioder. Należy także wspomnieć o zbrojach płytowych, kolczugach i hełmach ${ }^{32}$.

W skład broni zaczepnej jazdy husyckiej wchodziły miecze jednoręczne (półtoraręczne), nadziaki ${ }^{33}$ i kopie, ochronnej natomiast zbroje plytowe ${ }^{34}$, hełmy $^{35}$, $\operatorname{tarcze}^{36}$

26 P. Marczak, Wojny husyckie, s. 43-44.

27 Broń drzewcowa zakończona grotem, zaopatrzonym niekiedy w kolce na jego grzbiecie.

28 Należy wspomnieć w tym miejscu o partyzanach, a więc włóczniach o szerokim grocie ze skrzydłami, spisach szydłowatych oraz gizarmach z długimi, płaskimi grotami.

29 Zwana też siekańcem, maczuga na drewnianym bądź metalowym stylisku, wyposażona w głowicę, nabijaną ostrymi kolcami.

30 K. Ziółkowski, Husyckie wojska polne, s. 178.

31 J. Durdik, Sztuka wojenna husytów, Warszawa 1955, s. 82.

32 Z reguły szyszaki-szłomy bądź kapaliny.

33 Broń o przeznaczeniu obuchowo-siecznym, posiadająca drewniane stylisko i stalową dwustronną głowicę. Z jednej strony głowica była tępa, z drugiej zaś zaopatrzona w ostry kolec.

34 Niekiedy były to skórzane brygantyny, posiadające naszyte płytki metalowe.

35 Dominowały hełmy o trzech typach: szyszaki, kapaliny, salady.

36 Pawęże o niewielkich rozmiarach. 
oraz napierśniki. Kawaleria husycka posługiwała się także bronią miotającą w postaci niewielkich kusz ${ }^{37}$.

Jak już wcześniej stwierdzono bardzo duże wsparcie dla taboru husyckiego stanowiła artyleria. Reprezentowały ją dwa typy dział, a mianowicie hufnice ${ }^{38} \mathrm{i}$ taraśnice $^{39}$. Dział większego kalibru używano do burzenia murów i zdobywania miast ${ }^{40}$. Rolę pocisków pełniły kamienne kule, ponadto prymitywne granaty oraz kartacze. Przeznaczenie artylerii polegało przede wszystkim na „zmiękczaniu” szyku nieprzyjacielskiego, minimalizowaniu jego mobilności i zdolności bojowej.

Standardowo tabor husycki liczył 30-40 dział i 180 wozów bojowych ${ }^{41}$, podzielonych na minimum cztery rzędy. Liczba rzędów zależała w głównej mierze od ukształtowania terenu. Na podłożu podmokłym posuwanie się dziesięcio-, ewentualnie dwunastorzędowego taboru było niemożliwe, stąd dzielono go na mniejsze jednostki, łącząc dopiero w całość w bardziej sprzyjających warunkach terenowych. Przed bitwą często decydowano się na skrócenie taboru, zwiększając jego siłę ognia na wybranych odcinkach, szczególnie mocno atakowanych przez nieprzyjaciela. Pod warunkiem, że manewr ten został przeprowadzony szybko i sprawnie, zazwyczaj zdawał egzamin, skutkując wykrwawieniem atakujących.

Niewątpliwie tabor husycki był wysoce wyspecjalizowanym, a przy tym specyficznym szykiem bojowym, nastawionym zarówno na obronę, jak i działania zaczepne. W organizacji oraz ustawieniu taboru zwracano przede wszystkim uwage na ukształtowanie terenu (rów, bagno, wzgórze). Tego typu naturalne przeszkody miały chronić dostęp do wozów i być dużym utrudnieniem dla wojsk atakujących. Lokalizację taboru na terenie grząskim, poprzecinanym rowami czy jarami, a więc trudnym zwłaszcza dla nieprzyjacielskiej kawalerii stosowano i w wiekach późniejszych, niewątpliwie wzorując się na pomysłach husyckich. Warto podkreślić hierarchię będącą podstawą organizacji taboru. Dziesiętnicy oraz hetmani rzędów i wozów ściśle wykonywali rozkazy naczelnego hetmana, co wzmacniało dyscyplinę i morale. Kolejna kwestia to specjalizacja, dotycząca zarówno ról pełnionych przez poszczególnych żołnierzy, jak i posiadanego przez nich uzbrojenia. Nawiązując do żołnie-

37 K. Ziółkowski, Husyckie wojska polne, s. 184.

38 Posiadały krótkie lufy (do $20 \mathrm{~cm}$ ) i wąską komorę prochową. Montowano je na drewnianych lawetach, posiadających oś z kołami. Por. J. Sikorski Zarys historii wojskowości.

39 Charakteryzowały się długą lufą (nawet do $140 \mathrm{~cm}$ ) i brakiem wąskiej komory prochowej. Odlewano je z brązu, jak i kuto z żelaza.

40 Nazywano je bombardami i były one bardzo mało ruchliwe.

${ }_{41}$ T.M. Nowak, J. Wimmer, Historia oręża polskiego, s. 211. 
rzy należy podkreślić, że niektórym hetman przydzielał zadania tylko defensywne, związane $\mathrm{z}$ obroną taboru, innym z kolei ofensywne, zorientowane na atak. Broni używano zarówno w walce bezpośredniej, jak i rażąc przeciwnika. Specjalizacja w zakresie pełnionych na polu walki funkcji jak i różnorodności uzbrojenia, wzmacniała siłę husyckiego taboru, czyniąc husytów groźnym przeciwnikiem dla wyszkolonych wojsk niemieckich czy węgierskich.

\section{Praktyczne zastosowanie taboru husyckiego na polu bitwy. Recepcja na grunt polski}

Doskonałą ilustracją taktyki husyckiej i prowadzenia bitwy w oparciu o tabor było starcie pod Kutną Horą 21 XII 1421 r., w którym husyci Jana Žižki zmierzyli się z węgiersko-niemieckimi siłami Zygmunta Luksemburskiego. Rankiem 21 grudnia Czesi zaczęli zataczać tabor na wzgórzu pod Kutną Horą. Nie chcąc dopuścić do pełnego ukształtowania się fortecy niemiecka straż przednia zaatakowała husytów. Wówczas J. Žižka rzucił do przeciwnatarcia jazdę, która wprawdzie poniosła ciężkie straty, ale dała czeskiemu dowódcy czas potrzebny do wzmocnienia taboru. Próbująca zdobyć tabor z marszu awangarda Z. Luksemburczyka została odparta, a J. Žižka systematycznie powiększał linię wozów, wzmacniając ją artylerią od czoła. Na skrzydłach taboru stanęła przerzedzona kawaleria, odrzucając kilka szturmów nieprzyjaciela. Niemieckie ataki od czoła załamywały się w wyniku ostrzału husyckiej artylerii i kusz. W momencie, gdy opór Czechów tężał Kutną Horę niespodziewanie opanowali Niemcy. Jeden z oddziałów zamiast na pole bitwy omyłkowo trafił do miasta, a patrycjat podjął decyzję o otwarciu bram. Zwolennicy husytów zostali wymordowani. Husycki dowódca zareagował błyskawicznie wycofując tabor w kierunku Kolina. Epilog tego starcia nastąpił 8-9 I 1422 r. pod Habrem i zakończył się świetnym zwycięstwem husytów. Zniszczeniu uległa niemiecka straż tylna, a w ręce Czechów wpadł także obóz wroga ${ }^{42}$. $\mathrm{Z}$ innych bitew warto wymienić starcia pod Sudomierzem (25 III 1420 r.) ${ }^{43}$, Uściem (16 VI 1426 r. $)^{44}$, Horką (3 I 1431 r. $)^{45}$, Trzebnicą (13 V 1433 r.) ${ }^{46}$. Trud-

\footnotetext{
42 S. Turnbull, The Hussite Wars, Oxford 2004, s. 11-12.

43 P. Cornej, P. Belina, Slavné bitvy, s. 40.

44 M. Plewczyński, Wojny Jagiellonów z wschodnimi i południowymi sąsiadami Królestwa Polskiego w XV wieku, Oświęcim 2014, s. 25.

45 R. Primke, M. Szczerepa, W. Szczerepa, Wojny husyckie na Śląsku, s. 87-89.

46 Tamże, s. 110.
} 
no także pominąć bratobójcze starcie pomiędzy husyckimi radykałami a odłamem umiarkowanym i wspierającymi ich katolikami pod Lipanami (30 V 1434 r.) $)^{47}$.

Bitwa pod Kutną Horą pokazała jak ważną rolę w formowaniu taboru odgrywała topografia terenu. W tym przypadku było to wzgórze, mające utrudnić atak kawalerii Z. Luksemburczyka i zniwelować atut w postaci przewagi liczebnej. Krzyżowcy próbowali wyzyskać atut zaskoczenia i uderzając z marszu, zająć tabor. Taktyka taka dawała szanse powodzenia, gdyż wagenburg nie był jeszcze do końca zatoczony. Doskonale wiedzieli o tym atakujący. $Z$ tych też względów szturmowali pozycje husytów w sposób niezwykle zacięty. Wytrawny wódz husycki, J. Žižka zachował jednak zimną krew wiążąc krzyżowców jazdą i konsekwentnie formując tabor. Bardzo ważną rolę w bitwie odegrała artyleria, skutecznie rażąc nacierających i paraliżując ataki czołowe. W krytycznym momencie bitwy husycki dowódca zareagował w sposób właściwy, nie narażając taboru na mogącą przynieść dalsze straty walkę, lecz wycofując go w kierunku Kolina.

Szyk taborowy odegrał także znaczącą rolę w kampaniach wojennych prowadzonych przez wojsko polskie oraz Rzeczypospolitej Obojga Narodów w XV-XVII w. Rola ta przejawiała się przede wszystkim w sposobach użycia taboru na polu bitwy i recepcji pomysłów husyckich przez dowodzących wojskami polskimi. Warto również zwrócić uwagę na modyfikację wzorców husyckich, co w niektórych przypadkach było konieczne w zależności od zaistniałych warunków taktyczno-operacyjnych. Dążąc do prześledzenia znaczenia taboru husyckiego dla wojskowości polskiej w XV-XVII w., wybrano kilka bitew, będących modelowanymi przykładami walki w oparciu o tabor i jego zastosowanie. Należy w tym miejscu wyszczególnić batalie pod Świecinem, Obertynem i Kumejkami.

\section{Świecino 17 IX 1462 r.}

W bitwie tej, będącej szerszym fragmentem działań strony polskiej i krzyżackiej, określanych w historiografii jako wojna trzynastoletnia, doborowa oraz dowodzona przez podkomorzego sandomierskiego Piotra Dunina, armia polska w sile około 2 tys. żołnierzy pokonała nieco liczniejsze wojska krzyżackie Fritza Rawenecka, Kaspara

47 Starcie miało szczególny przebieg przede wszystkim dlatego, że radykałom nie udało się zamknąć otwartego wcześniej taboru, co przypieczętowało ich klęskę, zob. P. Marczak, Wojny husyckie, s. 110-111. 
von Nostitza i Eryka II Pomorskiego ${ }^{48}$. Strona polska rozbiła obóz na wzór husycki, $\mathrm{z}$ ustawionym $\mathrm{w}$ czworobok taborem, złożonym z wozów spiętych łańcuchami (tzw. połączenie „koło w koło”). Ochronę taboru stanowił rów, a także niewielki wał. Polski dowódca do maksimum wykorzystał topografię terenu, lokalizując tabor na wzgórzu, otoczonym zatoką leśną. Natomiast dostęp do wody umożliwiało jezioro Rogoźnica ${ }^{49}$.

Zgodnie z decyzją P. Dunina cała armia polska stanęła w polu, za wozami pozostała natomiast słabiej wyszkolona milicja gdańska. W ten sposób tabor stał się oparciem dla walczących wojsk, dawał także możliwość schronienia i prowadzenia obrony, w wypadku uzyskania przewagi przez wojska zakonne. Pomysł ten ocenić wypada jako nowatorski, odbiegający od schematów husyckich, zorientowanych przede wszystkim na wykrwawienie nacierającego przeciwnika i przeprowadzenie kontrataku z taboru w późniejszej fazie bitwy. Zamiarem strony polskiej było rozstrzygnięcie starcia $\mathrm{w}$ otwartym polu, ze względu na wąski, utrudniający ewentualny odwrót teren. Temu celowi podkomorzy P. Dunin podporządkował ustawienie swych wojsk, grupując na lewym skrzydle wyposażoną $\mathrm{w}$ kusze piechotę, osłanianą przez jazdę rozlokowaną w przestrzeni pomiędzy taborem a brzegiem jeziora Rogoźnica. Umożliwiało to prowadzenie w oparciu o tabor aktywnej obrony i współdziałanie piechoty oraz jazdy.

Inicjatywa w początkowej fazie bitwy należała do Polaków, którzy pod wodzą Pawła Jasieńskiego uderzyli na jazdę krzyżacką, powodując osłabienie wrogiego centrum. Następnie doszło do zaciętej, trzygodzinnej i nierozstrzygniętej walki kawalerii obu stron ${ }^{50}$. Wychodząc naprzeciw ówczesnym obyczajom bitwę przerwano ${ }^{51}$. Obie armie wycofaly się do swych taborów, a przerwę wykorzystano na uzupełnienie uzbrojenia, opatrzenie rannych i krótki odpoczynek ${ }^{52}$. Po wznowieniu bitwy Krzyżacy zaskoczyli polską jazdę, ale P. Dunin wsparł ją piechotą, prowadzącą gęsty ostrzał z kusz ${ }^{53}$. Był to kluczowy moment starcia. Wojska zakonne próbowały bezskutecznie kontratakować, lecz śmierć F. Rawenecka ostatecznie złamała ich morale. Klęskę

48 Siły F. Rawenecka, K. von Nostitza i Eryka II Pomorskiego szacuje się na około 2,7 tys. ludzi. Prawie połowę tych wojsk stanowili chłopi; M. Biskup, Wojna trzynastoletnia, Kraków 1990, s. 64. 49 Tamże, s. 64.

50 J. Długosz, Annales seu cronicae incliti Regni Poloniae, lib. XII (Continuatio), Varsaviae 2006, s. 44.

51 Podobna przerwa miała również miejsce podczas polsko-krzyżackiego starcia pod Koronowem w $1410 \mathrm{r}$.

52 J. Długosz, Annales, s. 44.

53 J. Sikorski, Zarys historii wojskowości, s. 287-288. 
krzyżacką przypieczętowało rozerwanie taboru przez polską jazdę. Straty krzyżackie wyniosły około tysiąca zabitych, polskie były nieznaczne ${ }^{54}$.

W bitwie pod Świecinem zastosowany przez polską armię szyk taborowy odegrał bardzo istotną rolę. Tabor zabezpieczył dostęp do wody, stanowił również oparcie dla piechoty i jazdy, zarówno w kwestii ustawienia, jak i manewrów na polu bitwy. Polski dowódca, P. Dunin założył również, że wozy mogą dać schronienie armii, w wypadku gdyby walka w otwartym polu zakończyła się niepowodzeniem. Nie doszło do tego na skutek wzorowego wręcz współdziałania piechurów i kawalerii. Podczas starcia P. Dunin wykorzystał niektóre z pomysłów husyckich (topografia terenu, zmasowany ostrzał nieprzyjaciela), potrafil też z sukcesem wdrożyć własne rozwiązania (wyprowadzenie doborowej armii przed tabor). Batalia pod Świecinem potwierdziła ogólnie znaną tezę, że forteca złożona ze szczepionych łańcuchami wozów, jest bardzo trudna do rozerwania. Strona polska dokonała tego przy użyciu wyłącznie jazdy, ponosząc zresztą spore straty. Wydaje się, że byłyby one zdecydowanie niższe, gdyby atak jazdy został wsparty przez piechotę, a więc formację wyspecjalizowaną do zdobywania twierdz, jak również warownych obozów.

\section{Obertyn 22 VIII 1531 r.}

Za klasyczny, można by powiedzieć modelowy przykład bitwy rozegranej w oparciu o szyk taborowy, należy uznać konfrontację pod Obertynem 22 VIII 1531 r. Dowodzący wojskami polskimi hetman Jan Tarnowski odniósł znakomite zwycięstwo nad armią hospodara mołdawskiego Piotra Raresza (Petryły). Powodem konfliktu były pretensje, jakie P. Raresz zgłosił do Pokucia latem $1530 \mathrm{r}^{55}$

Armia mołdawska liczyła około 20 tys. żołnierzy, posiadała też 50 dział, w tym 20 większego kalibru ${ }^{56}$. Siłom tym J. Tarnowski mógł przeciwstawić 6 tys. ludzi i 12 dzial, czyli trzy razy mniej ${ }^{57}$. Wieczorem 21 sierpnia dowodzona przez portara suczawskiego, Mihułę jazda Mołdawian w liczbie 10 tys. podeszła do obozu polskie-

\footnotetext{
54 S. Herbst, Wojna trzynastoletnia. O bitwie pod Świecinem, Przegląd Historyczno-Wojskowy 7 (1934), nr 2, s. 310.

55 Część województwa ruskiego, najdalej wysunięty na południe skrawek terytorium państwa polskiego.

56 T. Korzon, Dzieje wojen i wojskowości, t. 1, s. 205.

57 M. Plewczyński, Obertyn, Warszawa 1994, s. 145, 169.
} 
go $^{58}$. Znajdował się on w widłach Czerniawy i Krwawego Potoku ${ }^{59}$. Była to głęboka kotlina, niemal zupełnie pozbawiona walorów obronnych. Hetman J. Tarnowski zawiadomiony o zbliżaniu się nieprzyjaciela podjął decyzję o przesunięciu wojsk na położone $2 \mathrm{~km}$ od obozu płaskowzgórze ${ }^{60}$. Nadawało się ono idealnie do zatoczenia taboru, umożliwiając zarazem szarżę husarii oraz ogień artylerii. Warto podkreślić, że pozycję osłaniał od strony północnej las, co w razie niepowodzenia dawało szanse odwrotu. Po sformowaniu liczącego 300 wozów taboru J. Tarnowski uzbroił go w artylerię (południowo-wschodni róg), rozmieścił również strzelców (ściana południowo-wschodnia i południowo-zachodnia $)^{61}$. W środku taboru stanął odwód 800 piechurów (tzw. hufiec pieszy manewrowy), zaś frontem do bramy przedniej hufiec czelny jazdy ${ }^{62}$. Forteca została również zabezpieczona okopem i zasiekami ${ }^{63}$.

Rankiem 22 sierpnia armia mołdawska stanęła przed polskim taborem. Mołdawscy harcownicy bezskutecznie próbowali wywabić Polaków z obozu ${ }^{64}$. Nastąpiła obustronna kanonada artyleryjska ${ }^{65}$. Liczniejsza artyleria przeciwnika uzyskała przewagę. Było to spowodowane m.in. użyciem tzw. organek, a więc zespołu kilku luf, prowadzących ogień ciągly ${ }^{66}$.

Decyzje hetmana J. Tarnowskiego podjęte w początkowej fazie starcia pod Obertynem pokazują, że polski dowódca postanowił bronić się w oparciu o tabor, wykrwawić przeciwnika i zaatakować w sprzyjającym momencie. Mamy w tym przypadku do czynienia z recepcją taktyki husyckiej, zwłaszcza w kwestii zatoczenia taboru. W dalszej części starcia wspomniana taktyka została znacząco zmodyfikowana. Strona polska kilkakrotnie otwierała tabor rzucając do przeciwuderzeń piechotę (rotmistrz Lambert Gnojeński) oraz jazdę (Stanisław Balicki, Andrzej Trojanowski, Janusz Święcicki, Hipolit Młodecki, Mikołaj Sieniawski). Działania te doprowadziły do osłabienia prawego skrzydła mołdawskiego i w konsekwencji klęski hospodara

\footnotetext{
58 A. Czołowski, Bitwa pod Obertynem 22 sierpnia 1531 roku, Lwów 1931, s. 28.

59 M. Plewczyński, Obertyn, s. 171.

60 Tenże, Wojny i wojskowość, s. 369.

61 Tamże, s. 370.

62 Liczył 430 husarzy, 310 strzelców oraz 159 kopijników, zob. M. Plewczyński, Obertyn, s. 176.

63 M. Stryjkowski, Kronika polska, litewska, żmudzka i wszystkiej Rusi, t. 2, Warszawa 1846, s. 396.

64 J. Bielski, Kronika polska Marcina Bielskiego, t. 2, wyd. K.J. Turowski, Sanok 1856, s. 1051.

65 M. Stryjkowski, Kronika polska, litewska, żmudzka, t. 2, s. 397.

66 Z. Spieralski, Kampania obertyńska 1531 roku, Warszawa 1962, s. 180-181.
} 
P. Raresza. Jest to wyraźne odejście od taktyki husyckiej. Husyci nie decydowali się bowiem na otwarcie taboru, gdy bitwa nie została całkowicie rozstrzygnięta. Hetman J. Tarnowski potrafił otworzyć tabor i we właściwym momencie go zamknąć, co tylko potwierdza jego kunszt dowódczy.

Rozstrzygnięcie batalii pod Obertynem nastąpiło w wyniku dynamicznego współdziałania polskiej piechoty (Hieronim Noskowski), która zabezpieczyła zdobyte wcześniej działa ${ }^{67}$ oraz hufców jazdy (Mikołaj Iskrzycki) ${ }^{68}$. Współpraca zaowocowała złamaniem szyku nieprzyjaciela i likwidacją jego prawej flanki. Decydujące dla ostatecznego zwycięstwa okazało się uderzenie odwodowego hufca walnego i zagłada centrum oraz lewego skrzydła Mołdawian. Podkomendni hospodara P. Raresza stracili w bitwie $46 \%$ stanu osobowego, czyli 7746 żołnierzy. Straty polskie wyniosły 256 żołnierzy $^{69}$. Możliwe, że jest to liczba zaniżona i faktycznie były one nieco wyższe ${ }^{70}$.

Bitwa pod Obertynem pokazała, że w oparciu o tabor można prowadzić zaciętą obronę, znacząco osłabić przeciwnika, a w sprzyjającym momencie zniszczyć w koncentrycznym uderzeniu piechoty i jazdy. Odnosząc znakomite zwycięstwo strona polska zastosowała zarówno sprawdzone pomysły husyckie (tabor na wzgórzu, nasycenie szyku dużą liczbą strzelców), jak i własne (otwieranie taboru w celu wykonywania przeciwuderzeń i osłabienia jednej z flanek nieprzyjaciela, użycie hufca odwodowego do rozstrzygającego uderzenia). Na uwagę zasługuje zwłaszcza współpraca wszystkich rodzajów broni, zarówno podczas prowadzonej obrony, gdy inicjatywa należała jeszcze do strony mołdawskiej, jak i w działaniach zaczepnych. Połączenie w oparciu o tabor obrony z dużą manewrowością jazdy zmusiło stronę mołdawską do dwóch poważnych błędów (nadmierne rozciągnięcie wojsk w kierunku północno-zachodnim, osłabienie prawej flanki), które okazały się decydujące w kontekście ostatecznego rezultatu starcia. W porównaniu z husyckim tabor polski okazał się bardziej dynamiczny, zdolny nie tylko do obrony, ale przede wszystkim do skutecznego ataku na znacznie liczniejszego przeciwnika. Bitwa obertyńska skłania do stwierdzenia, że od batalii pod Lipanami w 1434 r., a więc na przestrzeni niecałych stu lat taktyka walki w oparciu o szyk taborowy uległa znacznej modyfikacji,

\footnotetext{
67 S. Orzechowski, Żywot i śmierć Jana Tarnowskiego kasztelana krakowskiego i hetmana wielkiego koronnego, wyd. K.J. Turowski, Sanok 1855, s. 63.

68 Był to hufiec czelny oraz liczący 1816 żołnierzy odwodowy hufiec walny.

69 T. Korzon, Dzieje wojen i wojskowości, t. 1, s. 206.

70 M. Plewczyński, Obertyn, s. 218.
} 
przechodząc od wariantu zorientowanego na obronę do wyraźnie ofensywnego, umożliwiającego pełne współdziałanie poszczególnych rodzajów broni oraz manewrowanie przed szeregiem wozów.

\section{Kumejki - 16 XII 1637 r.}

Do starcia pod Kumejkami doszło w trakcie kozackiego powstania P. Pawluka. W bitwie stoczonej 16 XII 1637 r. dowodzona przez hetmana polnego koronnego, Mikołaja Potockiego armia polska w liczbie 4 tys. ${ }^{71}$ rozbiła około 20 tys. Kozaków P. Pawluka, wspieranych przez oddziały Karpo Skidana ${ }^{72}$. Powstańcy posiadali także niewielką przewagę $\mathrm{w}$ artylerii, dysponując ośmioma działami ${ }^{73}$, podczas, gdy strona polska miała ich sześćc ${ }^{74}$.

Zataczając tabor w Kumejkach, M. Potocki dążył do osłony przeprawy na Rosi i utrzymania połączenia z operującymi za rzeką chorągwiami kwarcianymi. Drugi z celów, jaki przyświecał hetmanowi, wiązał się z wykorzystaniem taboru do prowadzenia działań zaczepnych przeciwko armii P. Pawluka i jej zupełnego zniszczenia. Starając się zrealizować przyjęte założenia M. Potocki wydzielił ze swych wojsk straż przednią, dowodzoną przez znakomitego żołnierza, a zarazem warchoła i awanturnika Samuela Łaszcza. Zadania tej grupy koncentrowały się na działaniach zwiadowczych i patrolowych oraz naprowadzeniu wojsk powstańczych na polski tabor ${ }^{75}$. Polacy zaatakowali Drabówkę ${ }^{76}$ Moszny ${ }^{77}$, zabezpieczyli również most w Sachnówce. Dzięki pochwyconym „językom” strona polska doskonale orientowała się w zamiarach wroga, nastawionych na zepchnięcie Polaków w lasy i przerwaniu łączności ze znajdującymi za Rosją chorągwiami jazdy kwarcianej. Skuteczny rekonesans

71 Eryka Lasoty i Wilhelma Beauplana opisy Ukrainy, przeł. Z. Stasiewska, S. Meller, Warszawa 1972, s. 117.

72 Zdaniem Władysława Tomkiewicza armia kozacka składała się z 18 tys. żołnierzy: W. Tomkiewicz, Bitwa pod Kumejkami, Przegląd Historyczno-Wojskowy 9 (1937), nr 2, s. 250. Szymon Okolski natomiast szacował liczebność sił kozackich na 23 tys. ludzi; Sz. Okolski, Dyaryusz transakcyi wojennej między wojskiem koronnem i zaporoskiem w r. 1637, wyd. K.J. Turowski, Kraków 1858, s. 50.

73 M. Franz, Wojskowość Kozaczyzny Zaporoskiej, s. 210.

74 Sz. Okolski, Dyaryusz transakcyi wojennej, s. 44.

75 M. Gawęda, Powstanie kozackie 1637, s. 122.

76 Sz. Okolski, Dyaryusz transakcyi wojennej, s. 43.

77 Tamże, s. 46. 
S. Łaszcza umożliwił także zniszczenie zdążającego na pomoc P. Pawlukowi oddziału Bohdana Kizyma. Kozacy zostali zaskoczeni podczas przeprawy przez Dniepr i niemal całkowicie wycięci ${ }^{78}$.

Tabor kozacki składał się z sześciu rzędów wozów. Posuwając się w kierunku Kumejek był systematycznie szarpany przez żołnierzy S. Łaszcza. Po dotarciu na miejsce kozacki dowódca podjął decyzję o stoczeniu bitwy w zdecydowanie niekorzystnych dla siebie warunkach taktyczno-operacyjnych (teren wybrany przez Polaków, fałszywe informacje Kozaków o liczebności wojsk polskich). W międzyczasie hetman M. Potocki sformował dziesięciorzędowy tabor. Od czoła osłaniało go bagno i jazda, we wnętrzu pozostali natomiast dragoni oboźnego koronnego Mikołaja Bieganowskiego i chorągiew hetmańska. Obie te jednostki czynnie uczestniczyły w bitwie uderzając na wrogi tabor. Prawą stronę taboru osłaniali dragoni oraz S. Łaszcz, który zabezpieczał ich skrzydło i artylerię ${ }^{79}$.

Pierwsi próbowali zaatakować Kozacy. Nie mogli jednak całkowicie rozwinąć się ze względu na bagnisty teren. Początkowa faza bitwy przebiegała pod znakiem obustronnej kanonady artyleryjskiej ${ }^{80}$. Śmiałym i można powiedzieć graniczącym $\mathrm{z}$ brawurą pomysłem hetmana M. Potockiego, było otwarcie taboru oraz wyjście polskich dragonów, którzy ostrzelali nieprzyjaciela z muszkietów. Skonsternowało to stronę kozacką, powodując przegrupowania w taborze i przesunięcie na jego czoło najbardziej doświadczonych żołnierzy ${ }^{81}$. Wzmacniając nacisk artylerii, M. Potocki zamierzał „zmiękczyć” tabor nieprzyjaciela i jak najszybciej dokonać jego rozerwania $^{82}$. W odpowiedzi P. Pawluk skrócił tabor. Walka w taborze dwunastorzędowym dawała mu możliwość zwiększenia siły ognia na wybranych odcinkach, najmocniej atakowanych przez Polaków. Widząc manewr Kozaków, M. Potocki rzucił do ataku jazdę. Dwie szarże zostały odparte, trzecia doprowadziła jednak do rozerwania taboru przez polskich husarzy i pancernych ${ }^{83}$.

Przez lukę powstałą po rozerwaniu taboru, cała polska jazda zaczęła wlewać się do wnętrza kozackiej fortecy, gdzie doszło do bezpardonowej, chaotycznej walki na białą broń. Część Kozaków rzuciła się do ucieczki, zgrupowani jednak przy prawym

\footnotetext{
78 W. Tomkiewicz, Bitwa pod Kumejkami, s. 248.

79 Tamże, s. 252.

80 Z. Wójcik, Wojny kozackie w dawnej Polsce, Kraków 1989, s. 57.

81 Sz. Okolski, Dyaryusz transakcyi wojennej, s. 52.

82 M. Gawęda, Powstanie kozackie 1637, s. 141-142.

83 S. Okolski, Dyaryusz transakcyi wojennej, s. 54.
} 
boku oraz w czole taboru stawili Polakom twardy opór, próbując zamknąć wozy ${ }^{84}$. Ostatecznie przód taboru został zdobyty przez dragonów M. Bieganowskiego i żołnierzy S. Łaszcza, w momencie gdy syn hetmana Piotr Potocki wraz z podległą mu chorągwią podpalił kozackie wozy z prochem ${ }^{85}$. Wybuchłej paniki P. Pawluk nie potrafił już opanować. Niedobitki zebrał Dymitr Hunia i w oparciu o tzw. taborek ${ }^{86}$ wycofał się w kierunku Biłozera ${ }^{87}$. W bitwie poległo około 5-8 tys. Kozaków i 150 Polaków ${ }^{88}$. Klęska oznaczała koniec powstańczego zrywu Pawła Pawluka ${ }^{89}$, choć jeszcze przez kilka tygodni siły polskie musiały zmagać się z luźnymi watahami Kozaków.

Pod Kumejkami polski tabor spełnił swoją rolę, polegającą na osłonie przeprawy przez rzekę Roś i prowadzeniu działań zaczepnych przeciwko oddziałom P. Pawluka. Osłona przeprawy umożliwiła utrzymanie kontaktu z operującymi za rzeką chorągwiami kwarcianymi. Walka w oparciu o tabor prowadzona przez hetmana M. Potockiego w zasadzie tylko w kwestii ustawienia taboru (teren podmokły, bagna), nawiązywała do wojskowości husyckiej. Hetman zastosował szereg własnych, nowatorskich pomysłów, które zapewnily mu zwycięstwo nad pięciokrotnie liczniejszym przeciwnikiem. Pierwszy z nich polegał na wydzieleniu straży przedniej i prowadzeniu aktywnych działań o charakterze patrolowo-zwiadowczym. Przyczyniły się one do rozpoznania zamiarów strony kozackiej jeszcze przed rozpoczęciem bitwy. Kolejna kwestia to systematyczne szarpanie taboru kozackiego i naprowadzanie go na siły polskie. Manewrów tego typu próżno szukać w XV w., podobnie jak i otwierania taboru na krótki okres czasu, by z broni palnej ostrzelać nieprzyjacielską fortecę. Należy także pamiętać o właściwej reakcji polskiego dowódcy na skrócenie taboru przez P. Pawluka. Tabor skrócony charakteryzował się większą efektywnością ogniową na wybranych odcinkach obrony. Wspomniana reakcja polegała na uderzeniu na tabor jazdą i jego rozerwaniu. Zdobycie taboru siłami samej tylko jazdy (bez wsparcia piechoty), wypada uznać za prawdziwy majstersztyk polskiej sztuki wojennej,

\footnotetext{
84 M. Gawęda, Powstanie kozackie 1637, s. 155.

85 W. Serczyk, Na dalekiej Ukrainie, s. 335.

86 Taborek został sformowany z ocalałych Kozaków z czoła i prawej strony taboru właściwego oraz praktycznie nienaruszonego przez Polaków tyłu.

87 W. Tomkiewicz, Bitwa pod Kumejkami, s. 255-256.

88 M. Gawęda, Powstanie kozackie 1637, s. 172; W. Tomkiewicz, Bitwa pod Kumejkami, s. 257. Zdaniem W. Beauplana pod Kumejkami poległo 100 żołnierzy M. Potockiego, zob. Eryka Lasoty $i$ Wilhelma Beauplana, s. 117.

89 Kapitulację podpisano 24 XII 1637 r. pod Borowicą.
} 
nie spotykany praktycznie na polach bitew w siedemnastowiecznej Europie. Starcie pod Kumejkami pokazało, że podstawą rozerwania taboru jest szybkie uderzenie przełamujące (w tym wypadku jazda), wspierane dodatkowo ogniem artylerii oraz dragonów.

\section{Podsumowanie}

$\mathrm{W}$ niniejszym artykule postawiono hipotezę o znaczącym wpływie szyku taborowego husytów na rozwój polskiej wojskowości w XV-XVII w. Na podstawie analizy wybranych bitew (Świecino, Obertyn, Kumejki) należy podkreślić, że polscy dowódcy wykorzystali niektóre z pomysłów husyckich, wprowadzili też szereg własnych, przyczyniając się do ewolucji szyku taborowego w zakresie jego wykorzystania na polu bitwy. Recepcja rozwiązań husyckich dotyczyła przede wszystkich ustawiania taboru na terenie podmokłym, wąskim, trudnym do rozwinięcia się dla wrogiej piechoty bądź jazdy. Na wzór husycki tabor nasycano także dużą ilością artylerii oraz ręcznej broni palnej. Zasadniczym zmianom nie uległ także sposób grupowania taboru. Poszczególne wozy łączono „koło w koło”, a tabor posiadał kształt owalny bądź czworoboczny. Zwykły szyk marszowy liczył cztery lub sześć rzędów wozów, przed bitwą dokonywano jego przeformowania tworząc bardziej skuteczny w obronie tabor złożony z dziesięciu bądź dwunastu rzędów. Skrócony tabor, z reguły czworoboczny, był bardziej efektywny pod względem ogniowym, stanowił także ze względu na ścisłe ustawienie wozów i plątaninę dyszli oraz łańcuchów fortecę bardzo trudną do zdobycia.

Innowacyjne pomysły polskie w zakresie wykorzystania taboru na polu bitwy można zauważyć już w bitwie pod Świecinem, a więc w niespełna czterdzieści lat po wprowadzeniu tego sposobu walki na szerszą skalę. W starciu tym tabor zabezpieczał armii polskiej dostęp do wody, stanowił również oparcie w kwestii ustawienia i manewrowania dla walczących w polu doborowych wojsk podkomorzego sandomierskiego, P. Dunina. Pod Obertynem strona polska użyła taboru do aktywnej obrony, wykonując z jego wnętrza przeciwuderzenia, skutkujące osłabieniem jednej z flanek nieprzyjaciela i w konsekwencji klęską w bitwie. W batalii pod Kumejkami tabor osłaniał przeprawę wojsk polskich przez rzekę Roś, ułatwiając utrzymanie łączności z operującymi za rzeką chorągwiami kwarcianymi, odegrał też bardzo ważną rolę w prowadzeniu działań zaczepnych przeciwko powstańcom kozackim P. Pawluka.

Starcia pod Świecinem i Kumejkami pokazały, że głównym sposobem likwidacji taboru jest jego rozerwanie, dokonane za pomocą szybkiego uderzenia przełamującego jazdy wspieranej ogniem artylerii. Minimalizacja strat prawdopodobnie byłaby 
możliwa przy użyciu piechoty, a więc formacji wyspecjalizowanej do zdobywania warownych obozów.

Tytułem ostatecznej konkluzji należy podkreślić, że w XV-XVII w. polscy wodzowie dokonali prawdziwej ewolucji w zakresie prowadzenia walki w oparciu o szyk taborowy, przekształcając go z fortecy mało ruchliwej, głównie defensywnej, w ruchomy i mobilny szaniec zorientowany na systematyczne współdziałanie poszczególnych rodzajów broni, wykrwawienie nieprzyjaciela i zadanie mu rozstrzygającego ciosu w sprzyjającym momencie.

Nadesłany: 22 I 2018

Nadesłany po poprawkach recenzyjnych: 6 III 2018

Zaakceptowany: 15 III 2018

mgr Marcin Gomółka

Instytut Historii i Stosunków Międzynarodowych

Wydział Humanistyczny

Uniwersytet Przyrodniczo-Humanistyczny w Siedlcach

ul. Żytnia 39

08-110 Siedlce

gomolka.m@gmail.com

\section{The impact of Hussites' wagon forts on the Polish military art in the $15^{\text {th }}-17^{\text {th }}$ centuries. Background information}

The article discusses the role and significance of the wagon fort in the development of the Polish warfare of the $15^{\text {th }}-17^{\text {th }}$ centuries. The article presents the origin of the wagon fort, its purpose and organisation. The subsequent part of the paper covers the analysis of battles fought by the Polish army in $15^{\text {th }}-17^{\text {th }}$ centuries, which are model examples of the use of the wagon fort both due to the character of conducted activities and the manoeuvres used as well as tactical and operational solutions. Therefore, the analysis covered the battles of Świecino, Obertyn and Kumejki, focusing mainly on the emphasis of the ways the wagon fort is used on the battlefield as well as the reception of Hussite models by Polish commanders. The final part of the paper contains conclusions concerning the analysed research area. 